SCHOOL

EFFECTIVENESS

and $\mathrm{SCHOOL}$

IMPROVEMENT

An internutional
houmel of Resesecch,
Policy and Proctice
School Effectiveness and School Improvement

An International Journal of Research, Policy and Practice

\title{
Teacher and school determinants of teacher job satisfaction: a multilevel analysis
}

\section{João Lopes \& Célia Oliveira}

To cite this article: João Lopes \& Célia Oliveira (2020) Teacher and school determinants of teacher job satisfaction: a multilevel analysis, School Effectiveness and School Improvement, 31:4, 641-659, DOI: 10.1080/09243453.2020.1764593

To link to this article: https://doi.org/10.1080/09243453.2020.1764593

\section{Published online: 18 May 2020.}

Submit your article to this journal

Џll Article views: 1044

Q View related articles $\asymp$

View Crossmark data

4

Citing articles: 4 View citing articles $₫$ 


\title{
Teacher and school determinants of teacher job satisfaction: a multilevel analysis
}

\author{
João Lopes $\mathbb{1}^{\mathrm{a}}$ and Célia Oliveira (1D) \\ ${ }^{\mathrm{a} D e p a r t m e n t}$ of Applied Psychology, University of Minho, Braga, Portugal; ${ }^{\mathrm{b}}$ Faculty of Psychology, Education \\ and Sports, Lusófona University of Porto, Porto, Portugal
}

\begin{abstract}
Teacher job satisfaction is an essential factor for teachers' and school effectiveness and students' academic and educational achievement. The present research aims to identify variables that contribute to job satisfaction in a Portuguese sample of lower secondary education teachers, using data from the Teaching and Learning International Survey (TALIS) 2013. Two questionnaires were used to collect data: a school principal's questionnaire, and a teacher questionnaire. Hierarchical linear modelling was used to study the relation of school-level and teacher-level variables to job satisfaction. The results show that teacher-level variables are better predictors of teacher job satisfaction than school-level variables, except for the variable public/private school. In addition, variables related to interpersonal relations emerge as the most significant predictors of job satisfaction. The results suggest that, in order to improve, schools must take care of interpersonal relations, mainly at the classroom level, where most of the perceived job satisfaction seems to rest.
\end{abstract}

\section{ARTICLE HISTORY}

Received 29 August 2018

Accepted 30 April 2020

\section{KEYWORDS}

Teacher job satisfaction; multilevel analysis; teacherstudents relations; school climate; classroom discipline

\section{Introduction}

Teachers' action is one of the most critical, if not the most critical, variable for student learning (Ingersoll \& Collins, 2017). Research has consistently shown that students' engagement, persistence, and commitment to learning are all strongly related to teachers' daily classroom action (Baker et al., 2000; Martin et al., 2012; Wu et al., 2010). However, teachers are more likely to be effective if they are satisfied with their job and current work conditions (Skaalvik \& Skaalvik, 2014). Researchers have suggested that students of teachers who are satisfied with their jobs and have a strong sense of psychological wellbeing tend to be more successful academically than those who are emotionally exhausted or unsatisfied (Arens \& Morin, 2016; Day, 2008; Mclnerney et al., 2018).

Teachers' job satisfaction has been associated with teacher well-being and effective school functioning (Shoshani \& Eldor, 2016). Teachers who are satisfied with their jobs are typically more motivated, more enthusiastic, and more committed to the school's mission (Li \& Wang, 2016; Shoshani \& Eldor, 2016). In comparison with unsatisfied teachers, satisfied teachers tend to be less motivated to relocate from their schools or to abandon

CONTACT João Lopes joaols@psi.uminho.pt 
the teaching profession (Gersten, 2001; Skaalvik \& Skaalvik, 2011). Satisfied teachers also miss fewer working days, show higher levels of self-efficacy, and demonstrate better mental health (Nakata et al., 2013; Skaalvik \& Skaalvik, 2014).

The Teaching and Learning International Survey (TALIS), conducted in 2008 and 2013, examined a large number of issues related to the teaching profession, including teachers' job satisfaction (Organisation for Economic Co-operation and Development [OECD], 2010, 2014a). TALIS 2013 used representative samples from 34 countries/regions (24 countries in 2008), involving more than 104,330 teachers from lower secondary education. Portugal participated in TALIS 2008, TALIS 2013, and TALIS 2018 (of which results were recently released). TALIS is the most important series of surveys approaching the "learning environment and the working conditions of teachers in schools" (OECD, 2014a, p. 19). TALIS 2013 focused on teachers' perceptions of schoolwork conditions, the feedback received from school principals, teachers' professional development, teachers' pedagogical practices, teachers' sense of self-efficacy, classroom disciplinary climate, and school-level policies and practices (namely, school leadership).

It is worth mentioning that a significant number of studies about teachers' job satisfaction, published before and after the TALIS 2013 study, were motivated by concerns about teacher turnover and teacher attrition (e.g., Hahs-Vaughn \& Scherff, 2008; Henry et al., 2011; Skaalvik \& Skaalvik, 2011). These concerns seem to continue to be high on the agenda of some education systems. Glazer (2018), for example, maintains that public school teaching in the US is a temporary job and that more teachers leave the profession voluntarily than those who remain until retirement. den Brok et al. (2017) also found that although attrition among novice teachers in the Netherlands is somewhat lower than in the United Kingdom, United States, or Australia, it is still close to $15 \%$.

Teacher attrition and teacher turnover have been found to negatively affect student academic achievement, in part because teachers with higher qualifications are more likely to leave the profession (Clotfelter et al., 2007; Ronfeldt et al., 2013). However, not all educational systems share the same level of concern. In countries like the Republic of Moldova, Singapore, and Brazil, levels of attrition are low (UNESCO Institute for Statistics, 2017), although the reasons for this may differ. Sims (2017) analysed the TALIS 2013 data in England and concluded that job satisfaction is lower in England than in other Englishspeaking countries that participated in TALIS. Furthermore, English teachers are more likely to move from one school to another (although the difference is not significant). The quality of leadership and teacher cooperation seem particularly relevant factors for job satisfaction in English teachers.

In Portugal, Jesus (1996) and Jesus and Lens (2005) note that the majority of teachers would like to leave the profession. Flores (2014), using a sample of 3,000 teachers, found that the motivation of $61 \%$ of the participants had decreased since 2009 , as well as their professional motivation. More than $95 \%$ of the participants also commented that the bureaucracy had increased as well as external control over their work. Participants also considered that the media and some political decisions were responsible for the lowered appreciation of the teaching profession. Although these data suggest that Portuguese teachers have low job satisfaction, the most recent data from the UNESCO Institute for Statistics (2017) show that the teacher attrition rate of Portuguese primary teachers was $8.2 \%$ in $2012,10.2 \%$ in $2013,7.2 \%$ in 2014 , and only $1.9 \%$ in 2015 . In addition, the TALIS 2013 data show that Portuguese teachers' job satisfaction $(M=11.81$; as defined for this 
particular study) is almost on the mean of TALIS participant countries ( $M=11.98$; the midscore of the scale is 10). Moreover, if we consider "satisfaction with current work environment" (one of the dimensions of teacher job satisfaction in TALIS 2013, the other one being "satisfaction with the profession"), we find that Portugal $(M=12.43$; eighth place in 34 countries) is somewhat above the mean of TALIS participating countries $(M=12.11)$.

In Portugal, there are almost no studies about teacher job satisfaction (and most studies that do exist use non-representative samples). This fact, coupled with the significant between-countries variability in factors involved in teacher job satisfaction, motivated us to explore the critical issue of teacher job satisfaction in Portuguese teachers using the data from TALIS 2013.

\section{Teachers' job satisfaction and associated factors}

Generally, job satisfaction refers to how much a person enjoys the conditions in which they carry out their professional activity (Pepe et al., 2017). Both cognitive and affective features seem to be involved in the construct of job satisfaction. Job satisfaction stems from a positive perception about job conditions (Worrell et al., 2006): The individual perceives job conditions as rewarding and as fulfilling their personal goals, and this tends to increase their commitment to the job and the organisation.

Pepe et al. (2017) distinguish two main perspectives in the literature regarding job satisfaction: One perspective stresses the importance of personal factors for job satisfaction (e.g., cultural background, motivation for the profession, perception of student-teacher relations). Caprara et al. (2006), for example, found that teacher self-efficacy affects job satisfaction and student achievement, even when controlling for previous levels of achievement. Another perspective considers work and societal conditions (e.g., leadership style, salary, organisational equity) to be more important than personal factors for job satisfaction. Kwantes (2010), for instance, compared the equivalence of the construct job satisfaction in nine nations and concluded that national context differences explained $18.5 \%$ of the variance in job satisfaction.

\section{Teacher job satisfaction: a multilevel (systemic) perspective}

While researchers are naturally more interested in factors at any level that can explain most of the variance in job satisfaction, for most teachers, teacher job satisfaction will likely result from a unique combination of factors from different levels for a particular teacher (Skaalvik \& Skaalvik, 2015). For example, accountability policies, which are widely recognised by researchers as an important systemic factor for teacher job satisfaction, teacher stress, and burnout, also put schools under pressure (Saeki et al., 2018; Sugrue \& Mertkan, 2017; von der Embse et al., 2017). However, individual schools might deal differently with the pressure for academic results, consequently influencing their teachers in different ways. Finally, individual teachers, nested in specific schools, will likely perceive accountability according to individual predispositions and characteristics, and to the perceived organisational (school) reaction to accountability.

Although teachers' job satisfaction may share some characteristics, worldwide, international studies like TALIS (OECD, 2010, 2014a) have found significant between-countries and between-schools variability. According to Kwantes (2010), the evidence suggests that 
“... content areas of job satisfaction do not function equivalently across all cultural or national samples and, in fact, may not be perceived equally" (p. 148). In order to study teacher job satisfaction, it is, therefore, relevant to partition the variance of predictors across hierarchical levels and to specify the level of each predictor (Heck et al., 2010).

Although research about teacher job satisfaction is not typically designed in a multilevel perspective, there is a growing number of studies that explore the multilevel nature of predictors of teacher job satisfaction (e.g., Gil-Flores, 2017; Torres, 2018). K. Wang et al. (2019) examined data from United States TALIS 2013, using a multilevel regression and commonality analysis, and concluded that the percentage of low achievers in the classroom, classroom behaviour problems, classroom disciplinary climate, socioeconomic status (SES), school location, principal job satisfaction, school autonomy for instruction, participation among stakeholders, experience, teacher self-efficacy, teacher-student relationships, teacher cooperation, and effective professional development are all predictors of teacher job satisfaction. Of these, classroom disciplinary climate, participation among stakeholders, and teacher-student relationships are particularly significant predictors. Overall, the authors found that school and teacher factors were more relevant than student factors for teacher job satisfaction. Sun and Xia (2018) also used a multilevel structural equation modelling (SEM) strategy to analyse TALIS 2103 data from the United States. The authors found that distributed leadership is a significant predictor of teacher job satisfaction and that this relationship is partly mediated by teacher self-efficacy at both teacher and school levels.

Importantly, Zieger et al. (2019) stress that the organisers of the TALIS study themselves did not meet scalar invariance when they compared the results of the scales across countries. Consequently, the technical report of TALIS 2013 (OECD, 2014b) warns against the comparison of the scale scores across countries. Zieger et al. suggest that creating a scale for a single country and then using standard measurement invariance approaches to set the comparator nations would be an appropriate way to overcome comparability issues. Zieger et al. state, for instance, that the comparison between England and Portugal in TALIS scales is unreliable (because of problems with fit indices of scale invariance) but add that England is comparable with 13 other countries.

\section{Extra-school factors}

Some important factors, external to schools, such as educational policies, teachers' salaries, and professional prestige, have been associated with teacher job satisfaction (Ellison et al., 2018; Han et al., 2018; Lincove et al., 2015; Tuytens \& Devos, 2018). At present, teacher and school accountability for student performance are considered to be important factors in teacher job (in)satisfaction, stress, and attrition (Cochran-Smith et al., 2017; Ryan et al., 2017; von der Embse et al., 2016). Ingersoll and Collins (2017) contend that the teacher accountability movement is one of the most controversial and significant contemporary education reforms. According to these authors, in the US, the teacher accountability movement blames teachers for "the erosion of American economic competitiveness, the decline in student academic achievement, teenage pregnancy, juvenile delinquency, a decline in morals, gender and racial stereotyping and discrimination, and on and on" (p. 75). Still, accountability may be perceived differently in educational systems where school performance has implications in state financing, in comparison with educational systems where financing has no direct connection with school performance. 


\section{School-level factors}

Research on school-level factors that influence teacher job satisfaction has explored such variables as school size, class size, school leadership, school climate, school SES, and teacher autonomy (Dou et al., 2017; Giambona \& Porcu, 2018; Watson et al., 2017). Generally, research has found that school processes do make a difference for teacher job satisfaction, particularly career and working conditions, staff collegiality, administrative support, school SES, school climate, and student behaviour (Aldridge \& Fraser, 2016; Ghavifekr \& Pillai, 2016; Shen et al., 2012). The quality of relations of teachers with their colleagues and with students is also associated with higher levels of job satisfaction.

\section{Teacher-level factors}

The influence of demographic variables such as gender and teaching experience on teacher job satisfaction is unclear. Some studies report no significant relationship, while others report somewhat higher levels of satisfaction in female teachers and younger teachers (Aytac, 2015; Menon \& Athanasoula-Reppa, 2011).

Teacher self-efficacy has been reported as positively related to teacher job satisfaction (Klassen \& Chiu, 2010; H. Wang et al., 2015). Malinen and Savolainen (2016) found that teacher self-efficacy in managing behaviour had a positive effect on job satisfaction and a negative effect on burnout. Caprara et al. (2006) also found that perceived selfefficacy had a positive effect on teachers' ability to handle effectively various professional tasks, obligations, and challenges.

Another important and pervasive factor involved in teacher job satisfaction that can still significantly vary between countries, regions, schools, and classrooms (i.e., from teacher to teacher) is classroom disruption (Chiu \& Chow, 2011; Hecker et al., 2018). Classroom disruption is often referred to as a significant reason for teachers' emotional exhaustion (Carson et al., 2011), as a vital classroom stressor (Tsouloupas et al., 2014), and as time and energy consuming (Brouwers \& Tomic, 2000; Lopes \& Oliveira, 2017). According to Simón and Alonso-Tapia (2016), classroom disruption is one of the most frequent and harmful problems faced by teachers.

Summing up the literature on teacher job satisfaction, Pepe et al. (2017) state that "job satisfaction in teaching is derived from the gratification of higher-order needs such as positive social relationships, rather than lower-order needs (e.g., pay incentives)" and that "satisfaction with positive relationships with co-workers, parents, and students mitigates some of the adverse effects of teaching work" (p. 399).

Our study aims to explore the school-related and the teacher-related factors involved in teacher job satisfaction, using data from TALIS 2013 (OECD, 2014a). The following hypotheses guide this study:

(1) There is significant between-schools variation in teacher job satisfaction.

(2) Both school-related and teacher-related variables are involved in teacher job satisfaction, but teacher-related factors influence teacher job satisfaction more than schoolrelated factors.

(3) Interpersonal relations are important factors for teacher job satisfaction.

Having these hypotheses in mind, as well as the relevant literature about teacher job satisfaction, we tested the involvement of different variables in job satisfaction through 
multilevel analysis. At Level 1 (teacher level), teacher's age, gender, self-efficacy, and classroom disciplinary climate were considered as predictors of job satisfaction. At Level 2 (school level), school climate, the degree of distributed leadership, teacher-student relations, teacher cooperation, and the number of teachers in the school (school size) were hypothesised as predictors of job satisfaction.

\section{Method}

The present study used data from TALIS 2013. Two questionnaires were used to collect data: one questionnaire for school principals (to collect organisational data) and one questionnaire for teachers. The schools for this study are at the ISCED-2 level (International Standard Classification of Education). In Portugal, ISCED-2 corresponds to sevenththrough ninth-grade classes.

\section{Participants}

As described in the TALIS 2013 technical report (OECD, 2014b), Portuguese participants were recruited through a stratified two-stage probability sampling design. The target population is 1,318 schools and 46,088 teachers. However, 16 schools, with 258 teachers, were excluded because they had non-Portuguese curricula. The coverage of the target population is, therefore, $98.8 \%$ for schools and $99.4 \%$ for teachers.

In the first stage of the sampling procedure, 192 schools from all over the country were randomly selected through a probability proportional to size (PPS). Three thousand, eight hundred and eight teachers responded to the surveys, representing $94.4 \%$ school participation. The weighted estimated size of the teacher population for this sample is 44.494. In the second stage of the sampling procedure, 20 teachers from each school were randomly selected and invited to participate in the survey. The teacher involvement in participating schools was $91.7 \%$. Since we used school data and teacher data in the context of multilevel analysis, the International Database Analyzer from the International Association for the Evaluation of Educational Achievement Analyzer (IEA IDB Analyzer) allowed us to merge school and teacher files and to select the appropriate weight variables. The IDB Analizer "is a stand-alone software originally developed by the IEA Data Processing and Research Center (IEA DPC) for the use in IEA's large-scale surveys" (Becker et al., 2014, p. 28) Moreover, it is straightforward in the analysis of combined school data and teacher data.

After accounting for missing data, the Portuguese sample included 177 schools (161 public, 16 private) and 3,489 teachers (2,563 female, 926 male). The average number of teachers per school was 125.05 ( $S D=61.28$; $\operatorname{Min}=15$; $\operatorname{Max}=380)$. However, there were differences in the number of teachers between public $(M=131.31, S D=60.99)$ and private $(M=69.10, S D=34.55)$ schools. The average age of teachers was 44.81 years $(S D=7.50 ; \operatorname{Min}=15 ; \operatorname{Max}=68)$.

\section{Variables and measures}

We extracted two types of variables from the TALIS 2013 database: single variables obtained from responses to specific questions and latent continuous variables obtained 
from a confirmatory factor analysis (CFA) to a set of responses. In this last case, the latent variable is the combination of several observed variables. Classroom climate, for example, results from the combination of four observed variables (quiet classroom, pleasant atmosphere, disruptive noise, and interrupted lesson). After computation, the factor scores were rescaled to a metric of convenience, with a standard deviation of 2.0, where the value of 10 corresponds to the mid-point of the scale in which the items were originally measured (i.e., 2.5 points). Therefore, a result of 10 indicates average agreement with the items in the scale. A result above 10 indicates some agreement, and a result below 10 indicates some disagreement. The TALIS 2013 technical report (OECD, 2014b) provides complete information about the construction of the scales and indices developed through CFA.

\section{Job satisfaction}

Job satisfaction is the outcome variable for this study. In TALIS 2013, job satisfaction results from the combination of two indicators: satisfaction with current work environment (e.g., "All in all, I am satisfied with my job"; Cronbach's $a=.77$; composite reliability $[C R]=0.61$; average variance extracted $[\mathrm{AVE}]=.85$ ), and satisfaction with profession (e.g., "The advantages of being a teacher clearly outweigh the disadvantages"; Cronbach's $\alpha=.86 ; C R=.91$; $A V E=.71)$. The correlation between satisfaction with current work environment and satisfaction with profession is $r(3192)=.47, p<.01$. On the whole, job satisfaction results from the responses to eight items (Cronbach's $a=.82$ ), four from satisfaction with the current work environment, and four from satisfaction with the profession. All items in the scale were answered on a 4-point scale, where 1 corresponds to strongly disagree and 4 to strongly agree. The CR for the eight items is .87, and the AVE is .46. According to the transformation resulting from CFA, a result above 10 indicates some agreement with the item, and a result below 10 indicates some disagreement with the item.

\section{Teacher-related predictors}

In addition to teachers' age and gender, the following variables were considered as predictors of teacher job satisfaction at the teacher level.

Teacher self-efficacy. Teachers self-efficacy (TSE) refers to the perceived ability of the teacher to achieve classroom instructional and behavioural goals (Cronbach's $a=.77$; $\mathrm{CR}=0.90 ; \mathrm{AVE}=.57$ ). This variable is the average of three distinct features of TSE: efficacy in classroom management (e.g., "Get students to follow classroom rules"; Cronbach's $a=.81 ; C R=0.64 ; A V E=.87$ ), efficacy in instruction (e.g., "Craft good questions for my students"; Cronbach's $a=.75 ; C R=0.84 ; A V E=.57)$, and efficacy in student engagement (e.g., "Help my students value learning"; Cronbach's $a=.76 ; C R=0.85$; AVE =.59). Responses must be given on a scale ranging from strongly disagree (1) to strongly agree (4).

Classroom disciplinary climate. Classroom disciplinary climate refers to the teacher's perceived ability to control classroom order and/or classroom disruption. The variable was designed through a CFA (Cronbach's $a=.88 ; C R=0.92$; AVE $=.74$ ), taking into account the answers to four items (e.g., "There is much disruptive noise in this classroom"), ranging from never (1) to once a week or more (6). As referred in the TALIS technical report (OECD, 2014b), three items "were reverse coded due to their negative statement 
about classroom disciplinary climate and to ensure they had the same direction as the rest of the items" (p. 229).

\section{School-related predictors}

In addition to the number of teachers at the school, four other indicators, resulting from answers to the TALIS scales, were considered at the school level.

Teacher cooperation. Teacher cooperation refers to the perceived cooperation between teachers to effectively undertake student instruction. Teacher cooperation was measured by eight items (Cronbach's $a=.65 ; C R=0.80 ; A V E=.35$ ) that were composed from two scales: exchange and coordination for teaching (e.g., "Exchange teaching materials with colleagues"; Cronbach's $a=.74 ; C R=0.84 ; \mathrm{AVE}=.56$ ) and professional collaboration (e.g., "Teach jointly as a team in the same class"; Cronbach's $a=.56 ; \mathrm{CR}=0.75 ; \mathrm{AVE}=.43$ ).

School climate. School climate refers both to the perceived level of aggression and intimidation in the school and to the respect between staff members and between staff members and students (Cronbach's $a=.79 ; C R=0.83$; $A V E=.39$ ). Two scales were formed separately to represent school climate: school delinquency and violence (e.g., "Vandalism and theft"; Cronbach's $a=.84 ; C R=0.79 ; \mathrm{AVE}=.53$ ) and mutual respect (e.g., "The relationships between teachers and students are good"; Cronbach's $a=.74 ; C R=$ 0.81 ; AVE $=.53$ ). Each scale has four items; these were collected from the school principals.

Distributed leadership. Distributed leadership measures school principals' perception of how they share power with their staff and whether parents and students are permitted to participate in school decision making. Distributed leadership was measured by three items (e.g., "This school provides staff with opportunities to actively participate in school decisions"; Cronbach's $a=.78 ; \mathrm{CR}=0.85$; $\mathrm{AVE}=.60$ ).

Teacher-student relations. A Level 2 (school) measure was created by aggregating individual teachers' perceived teacher-student relations (previously described) within each school. This variable, therefore, represents the within-school mean for teacher-student relations. The variable seeks to measure the relations between teachers and students in a specific school. Four items measured teacher-student relations (e.g., "In this school, teachers and students usually get on well with each other"; "If a student from this school needs extra assistance, the school provides it"; Cronbach's $a=.73 ; C R=0.85$; AVE =.66).

\section{Model building}

The model building followed several steps. The first step was to create a null or unconditional model (one-way analysis of variance random effects model with no Level 1 or Level 2 predictors) to ascertain whether there is between-school variation in teacher job satisfaction. This first step addresses the question "Is there a (Level 2) school effect on the (Level 1) intercept of teacher job satisfaction, which represents the mean score?", and involves the calculation of the intraclass correlation coefficient (ICC) of the deviance statistic ( $-2 \mathrm{LL})$ and the design effect. In the second step, a random coefficient model was added to test for significant relationships between Level 1 predictors and job satisfaction and to test for differences between schools in each predictor. Finally, a third model, 
combining Level 1 and Level 2 variables, tested the relevance of both levels variables in the prediction of job satisfaction. The model incorporates predictors both at Level 1 and Level 2, and both the Level 1 intercept and the Level 1 slopes are predicted as random effects. Level 1 predictors were group-centred, and Level 2 predictors were grand-mean centred in the partially and fully conditional models. HLM 7 hierarchical linear and nonlinear modelling (Raudenbush et al., 2013) were used for the adjustment of models.

\section{Results}

Tables 1 and 2 show the descriptive statistics for teachers and for schools and the correlations between variables.

The descriptive statistics show that: (a) Portuguese teachers' job satisfaction is above the mid-point of the scale (10); (b) Portuguese teachers are somewhat older than the average of TALIS teachers $(M=42,51)$; (c) Portuguese teachers are positive about their relations with the students and about their ability to conduct classroom instruction and management; (d) although positive, teacher perception about classroom discipline is below the mean of other teacher-related variables; (e) school-level variables also show positive trends except for teacher cooperation that is just above the mid-point of the scale.

\section{Unconditional model}

Table 3 shows the correlations between school variables, and Table 4 shows the results for the unconditional or null model (the denomination comes from the fact that no predictors are included in the model). The goal of this model is to test whether there is betweenschool variation in job satisfaction. The model is the following:

Table 1. Descriptive statistics for teachers ( $N=3,489 ; 2,563$ female, 926 male).

\begin{tabular}{lcccc}
\hline & $M$ & $S D$ & Min & Max \\
\hline Job Satisfaction & 11.81 & 1.83 & 4.48 & 15.03 \\
Age & 44.81 & 7.50 & 24 & 68 \\
Self-efficacy & 13.76 & 1.31 & 8.06 & 15.45 \\
Class discipline & 10.50 & 1.96 & 5.57 & 14.36 \\
Descriptive statistics for schools $(N=177 ; 161$ public, 16 private) & & & \\
School climate & 12.85 & 1.70 & 8.24 & 16.75 \\
Distributed leadership & 12.67 & 1.77 & 8.89 & 16.54 \\
Teacher cooperation & 10.03 & 1.52 & 6.20 & 14.61 \\
Teacher-Student relations_mean. & 13.47 & 61.70 & 15 & 15.58 \\
Number_Teachers & 125 & & & 380 \\
\hline
\end{tabular}

Table 2. Correlations between teacher variables.

\begin{tabular}{lcccc}
\hline & 1 & 2 & 3 & 4 \\
\hline Job Satisfaction & - & & & \\
Age & $.044^{* *}$ & - & & \\
Self-efficacy & $.257^{* *}$ & .003 & & \\
Class discipline & $.262^{* *}$ & $-.055^{* *}$ & $.227^{* *}$ & - \\
\hline
\end{tabular}

${ }^{* *} p<0.01$. 
Table 3. Correlations between school variables.

\begin{tabular}{|c|c|c|c|c|c|}
\hline & 1 & 2 & 3 & 4 & 5 \\
\hline School climate & - & & & & \\
\hline Distributed leadership & $.122^{* *}$ & - & & & \\
\hline Teacher cooperation & $.056^{* *}$ & .012 & - & & \\
\hline Teacher-Student relations_mean & $.320^{* *}$ & $.064^{* *}$ & $.107^{* *}$ & - & \\
\hline Number_Teachers & .001 & $.035^{* *}$ & -.006 & $-.183^{* *}$ & - \\
\hline
\end{tabular}

${ }^{* *} p<0.01$.

Table 4. Unconditional hierarchical linear model.

\begin{tabular}{|c|c|c|c|c|c|}
\hline \multicolumn{6}{|c|}{ Estimated fixed effects } \\
\hline Parameter & Coefficient & SE & $d f$ & $t$ & $p$ \\
\hline $\begin{array}{l}\text { Intercept } \\
\text { Estimated random effects }\end{array}$ & 11.80 & 0.04 & 176 & 247.21 & 0.000 \\
\hline Parameter & $S D$ & VC & $d f$ & $x^{2}$ & $p$ \\
\hline $\begin{array}{l}u_{0} \text { (variation among schools) } \\
r \text { (variation within schools) }\end{array}$ & $\begin{array}{l}0.49 \\
1.77\end{array}$ & $\begin{array}{l}0.24 \\
3.12\end{array}$ & 176 & 445.48 & 0.000 \\
\hline
\end{tabular}

Note: $\mathrm{VC}=$ variance component.

Level 1 Model

$$
\text { JobSats }=\beta_{0 j}+r_{i j}
$$

Level 2 Model

$$
\beta_{0 j}=\gamma_{00}+u_{0 j}
$$

In this model, $\beta_{0 j}$ represents the Level 1 intercept term, which is a function of an intercept term at Level $2\left(\gamma_{00}\right)$ and of a Level 1 residual term $\left(r_{i j}\right)$. The Level 1 intercept term $\left(\beta_{0 j}\right)$ is a function of the grand mean $\left(\gamma_{00}\right)$ of schools, plus a random term $\left(u_{0 j}\right)$, which means that the intercept is modelled as a random effect.

The null or unconditional model shows an average of 11.80 for teacher job satisfaction, 1.80 points above the mid-point of the scale. Within-school variance for teacher job satisfaction is $\sigma^{2}=3.12$, and between-school variance is $\tau=0.24, p<0.001$. The intraclass correlation is $0.07(0.24 /[3.12+0.24])$, which means that differences between schools explain $7 \%$ of the variability in teacher job satisfaction, and differences between individual teachers explain 93\%. The significant between-schools variation for job satisfaction shows that there is still considerable residual variation in job satisfaction yet to be explained and that a model with additional predictors is needed. The design effect ${ }^{1}$ (Design Effect $=1$ + [nc-1] ICC) is 2.35. According to some authors (e.g., Muthén \& Satorra, 1995), a design effect greater than 2.0 indicates the need for hierarchical linear modelling.

\section{Hierarchical linear modelling combining teacher-level and school-level predictors of job satisfaction}

Once it was determined that job satisfaction significantly varies between schools, the next step was to build a model including both Level 1 and Level 2 predictors of job satisfaction. Before running the complete model, hypothesised predictors were individually entered into the Level 1 regression equation to test their importance as predictors. This process 
revealed that teachers' age and gender did not contribute to the explanation of job satisfaction at Level 1 and that the number of teachers at the school, the mean teacherstudent relations, and distributed leadership did not contribute to the model at Level 2. We, therefore, decided to exclude those variables from the model. The complete model included teacher self-efficacy and classroom discipline as teacher-level predictors of job satisfaction, and the type of school (public/private), school climate, and teacher cooperation as school-level predictors of job satisfaction (see Table 5). The model is as follows:

Level 1 Model

$$
\text { JobSats } \left.=\beta_{0}+\beta_{1} * \text { (Self_Eff. }\right)+\beta_{2} *(\text { Clas_Dis })+r
$$

Level 2 Model

$$
\begin{aligned}
& \left.\left.\beta_{0}=\gamma_{00}+\gamma_{01} * \text { (PubPriv }\right)+\gamma_{02} *(\text { SchoolClim })+\gamma_{03} * \text { (Teach_Coop }\right)+u_{0} \\
& \beta_{1}=\gamma_{10} \\
& \beta_{2}=\gamma_{20}
\end{aligned}
$$

The results show that: (a) every variable retained in the final model is a significant predictor of teacher job satisfaction; (b) teacher-level variables are better predictors of job satisfaction than school-level variables, except for the characteristic public/private; (c) type of school is the best single predictor of job satisfaction (job satisfaction is 0.83 higher in private schools); (d) at the teacher level, perceived teacher-student relations is the best predictor of job satisfaction.

The unexplained variance among schools in the final model is $u_{0 j}=0.17$, which represents a $29.17 \%$ reduction compared to the null model $\left(u_{0 j}=0.24\right)$. Still, a significant portion of the variance remains unexplained by the model. There was a significant increase in model fit from the unconditional model (deviance $=14042.00$ ) to the complete model

\begin{tabular}{|c|c|c|c|c|c|}
\hline \multicolumn{6}{|c|}{ Estimated fixed effects } \\
\hline Parameter & Coefficient & $S E$ & $d f$ & $t$ & $p$ \\
\hline Intercept & 10.89 & 0.20 & 173 & 53.58 & 0.000 \\
\hline Public/private & 0.83 & 0.19 & 173 & 4.40 & 0.000 \\
\hline School climate & 0.08 & 0.026 & 173 & 3.01 & 0.003 \\
\hline Teacher cooperation & 0.06 & 0.02 & 173 & 2.22 & 0.028 \\
\hline Teacher self-efficacy & 0.22 & 0.02 & 3309 & 9.33 & 0.000 \\
\hline Classroom discipline & 0.18 & 0.02 & 3309 & 10.81 & 0.000 \\
\hline \multicolumn{6}{|l|}{ Estimated random effects } \\
\hline Parameter & $S D$ & VC & $d f$ & $x^{2}$ & $p$ \\
\hline$u_{0}$ (variation among schools) & 0.42 & 0.17 & 173 & 339.67 & 0.000 \\
\hline$r$ (variation within schools) & 1.62 & 2.62 & & & \\
\hline
\end{tabular}
(deviance $=13437.92$ ), represented by a significant decrease in the deviance of the model $(14042.00-13437.92=604.08, p<.001)$.

Table 5. Hierarchical linear model for job satisfaction with teacher-level and school level predictors.

Note: VC = variance component. 


\section{Discussion}

Three primary hypotheses guided our study: (1) There is significant between-schools variation in teacher job satisfaction; (2) both school-related and teacher-related variables explain teacher job satisfaction, but teacher-related factors influence teacher job satisfaction more than school-related factors; (3) interpersonal relations are important factors for teacher job satisfaction.

The results show that there is significant between-school variation in job satisfaction. However, differences between schools represent no more than $7 \%$ of the explained variance in job satisfaction. In a study conducted in Spain, Gil-Flores (2017) found that $11.29 \%$ of the variance in job satisfaction corresponded to variability between schools and $88.71 \%$ to variability between teachers. This finding suggests that proximal variables, rather than distal variables, more fully explain job satisfaction. Still, we must stress that in our final model, a significant portion of the variance in job satisfaction remains unexplained. We can, therefore, hypothesise that other school-level variables, not considered in our model, explain significant variability in teacher job satisfaction. It seems unlikely, however, that the relative weight of teacher and school variables in job satisfaction would change significantly with the introduction of new variables. Still, it is important to note that the low autonomy of Portuguese public schools may explain the somewhat low between-school variability in job satisfaction. Public schools have no financial autonomy; principals cannot hire teachers; the disciplinary regulations are set by law, etc. Unlike in other countries, salary may contribute to job satisfaction, but this will not have great explanatory power because it is the same for every school. In this context, it is not surprising that the difference between schools in job satisfaction is moderate.

The difference in job satisfaction between private and public schools is significant. Although teachers from private and public schools are moderately satisfied, teachers from private schools $(M=12.67, S D=1.74, n=16)$ are more satisfied than teachers from public schools $(M=11.72, S D=1.82, n=161), t=-8.54, p<.001)$. This difference may reflect the greater autonomy of private schools. For instance, private schools can select their students and teachers, and they can set their disciplinary regulations. Also, private schools that participated in TALIS 2013 are much smaller $(M=69$ teachers) than public schools ( $M=131$ teachers).

Analysing the variables retained in the final model, it seems that the best predictors of job satisfaction involve proximal interpersonal relationships, specifically, relations with the students. For instance, teacher self-efficacy and classroom discipline (teacher-level variables) better predict job satisfaction than teacher cooperation. As Pepe et al. (2017) state, "job satisfaction in teaching is derived from the gratification of higher-order needs such as positive social relationships, rather than lower-order needs (e.g., pay incentives)" and "satisfaction with positive relationships with co-workers, parents, and students mitigates some of the adverse effects of teaching work" (p. 399).

At the school level, other than for the variable public/private, the school climate predicts job satisfaction, although weakly. Past research suggests that school climate positively influences teacher job satisfaction (Aldridge \& Fraser, 2016; Ghavifekr \& Pillai, 2016) and commitment to the organisation (Sezgin, 2010). Malinen and Savolainen (2016) also found that the school climate has a positive effect on job satisfaction and burnout, partly mediated by self-efficacy. Overall, most studies, including our own, have 
found a positive relationship between school climate and job satisfaction. Fluctuations in the strength of the relation may reflect differences in the definition and the measurement of the school climate.

The results also show that teacher cooperation predicts job satisfaction minimally. Drossel et al. (2019) state that teacher cooperation is an important indicator of school quality, reducing teacher stress and improving student academic achievement, and contend that "the subjective value component, in particular, personal relevance, is the decisive factor in determining why teachers cooperate in teaching-related forms of cooperation" (p. 9). Our participants anticipated very moderate personal gains from teacher cooperation, suggesting that they did not perceive teacher cooperation as very relevant for job satisfaction.

At the teacher level, we found two significant predictors of job satisfaction: classroom discipline and teacher self-efficacy. The predictive value of these factors suggests that interpersonal relations matter for job satisfaction. The literature often refers to classroom misbehaviour as one of the most severe problems that teachers face in schools (Simón \& Alonso-Tapia, 2016), and has long emphasised that classroom misbehaviour is time and energy consuming and increases the risk for teacher burnout (Brophy, 1996; Lewis et al., 2005). Classroom misbehaviour may also harm teacher-student relations and reduce teachers' sense of professional wellbeing (Carson et al., 2011). The results we obtained about teacher efficacy are unsurprising since the literature has been conclusive about the importance of teacher self-efficacy for job satisfaction (e.g., Caprara et al., 2006; H. Wang et al., 2015).

It is important to note that teachers' age, gender, the number of teachers in the school (school size), teacher-student relations (at the school level), and the extent of distributed leadership did not help to explain job satisfaction. In our study, most participants have a long experience in teaching, and this may have reduced the variability of the results. The research on teacher gender and job satisfaction tends to be inconclusive. According to Aytac (2015), female teachers may be more satisfied because teaching is usually perceived as a female profession. However, male teachers can be precisely those people that choose to become teachers, therefore balancing perceptions that could be more negative. The findings concerning school size reinforce findings in the literature that teachers might be more concerned about class size than school size (Biggs, 1998; Pedder, 2006; Watson et al., 2017).

Distributed leadership, contrary to what was found in Singapore (Torres, 2018) but similar to what was found in Spain (Gil-Flores, 2017), did not predict job satisfaction in our study. Most likely, the structure of the educational systems may be an important reason for discrepancies. In Portugal, the central government largely determines the governance of the schools. School principals have limited autonomy, so they cannot easily share leadership. The limited autonomy may explain why distributed leadership was not an influential factor in our study.

Overall, our results seem to confirm the position of Pepe et al. (2017) that teacher job satisfaction has much to do with higher order needs, specifically, positive social relations. Although principals of public schools, in Portugal, cannot determine or influence teachers' professional careers, they may still perceive the development of positive relations in the classroom (more than in the school, as a whole) as an effective way to increase teacher job satisfaction and, consequently, to contribute to student academic achievement and 
educational growth. The results also suggest that job satisfaction is more dependent upon classroom processes and only then (and in a more diffuse way) to broader school processes.

Finally, the results suggest that the most important predictors of job satisfaction of Portuguese teachers (classroom disciplinary climate and teacher self-efficacy) are similar to predictors found in other countries that participated in TALIS 2013. However, schoollevel factors like the quality of leadership or teacher cooperation do not explain Portuguese teachers' job satisfaction, as was the case for other TALIS 2013 participating countries (e.g., U.S., England). Some idiosyncrasies of the Portuguese educational system (e.g., low autonomy of school principals and teachers) may help explain these findings.

\section{Limitations and implications for practice}

The main limitation of this study is that it can deal only with the variables that are included in the TALIS 2013 database. It would be interesting to consider other variables that might be involved in teacher job satisfaction, such as student academic achievement or the perceived social status of the profession. The omission of these explanatory variables may raise endogeneity problems (Roberts $\&$ Whited, 2013). Despite the absence of some potentially relevant variables in the model, our dependent variable (job satisfaction) may be influenced by one or several explanatory variables. Abdallah et al. (2015) stress that endogeneity "would result in the error term being correlated with the explanatory variables, thereby violating a basic assumption behind ordinary least squares (OLS) regression analysis" (p. 791).

Our results seem to confirm suggestions in the literature that actions to improve teacher job satisfaction should focus on classrooms, in particular, teacher-student relationships. Assisting teachers with classroom instruction and management may be effective ways to increase teacher effectiveness, perceived self-efficacy, and job satisfaction, and consequently, improve student learning and well-being.

\section{Note}

1. "The design effect quantifies the effect of independence violations on standard error estimates and is an estimate of the multiplier that needs to be applied to standard errors to correct for the negative bias that results from nested data." (Peugh, 2010, p. 91)

\section{Disclosure statement}

No potential conflict of interest was reported by the authors.

\section{Notes on contributors}

João Lopes holds a PhD in Psychology, and he is a hired Professor in the School of Psychology of the University of Minho. His research interests are in the areas of learning disabilities, reading instruction, classroom behaviour problems, and classroom management. He has written more than a dozen books on these subjects, as well as research papers.

Célia Oliveira holds a PhD in Experimental Psychology at the University of Minho. She holds a Master Degree in Clinical Psychology with a thesis titled "Working Memory in a Group of School Aged 
Children With ADHD". As a school psychologist, she focused on the developmental problems of handicapped children and on the learning problems of school-aged children. She currently teaches Psychology at the O'Porto Lusófona University.

\section{ORCID}

João Lopes (1) http://orcid.org/0000-0001-5005-120X

Célia Oliveira (iD http://orcid.org/0000-0002-8252-7337

\section{References}

Abdallah, W., Goergen, M., \& O'Sullivan, N. (2015). Endogeneity: How failure to correct for it can cause wrong inferences and some remedies. British Journal of Management, 26(4), 791-804. https://doi. org/10.1111/1467-8551.12113

Aldridge, J. M., \& Fraser, B. J. (2016). Teachers' views of their school climate and its relationship with teacher self-efficacy and job satisfaction. Learning Environments Research, 19(2), 291-307. https:// doi.org/10.1007/s10984-015-9198-x

Arens, A. K., \& Morin, A. J. S. (2016). Relations between teachers' emotional exhaustion and students' educational outcomes. Journal of Educational Psychology, 108(6), 800-813. https://doi.org/10. 1037/edu0000105

Aytac, T. (2015). The effect of gender on teachers' job satisfaction: A meta-analysis. The Anthropologist, 20(3), 385-396. https://doi.org/10.1080/09720073.2015.11891742

Baker, L., Dreher, M. J., \& Guthrie, J. T. (2000). Why teachers should promote reading engagement. In L. Baker, M. J. Dreher, \& J. T. Guthrie (Eds.), Engaging young readers: Promoting achievement and motivation (pp. 1-16). The Guilford Press.

Becker, A., Dumais, J., LaRoche, S., \& Mirazchiyski, P. (2014). TALIS user guide for the international database. OECD.

Biggs, J. (1998). Learning from the Confucian heritage: So size doesn't matter? International Journal of Educational Research, 29(8), 723-738. https://doi.org/10.1016/S0883-0355(98)00060-3

Brophy, J. (1996). Teaching problem students. The Guilford Press.

Brouwers, A., \& Tomic, W. (2000). A longitudinal study of teacher burnout and perceived self-efficacy in classroom management. Teaching and Teacher Education, 16(2), 239-253. https://doi.org/10. 1016/S0742-051X(99)00057-8

Caprara, G. V., Barbaranelli, C., Steca, P., \& Malone, P. S. (2006). Teachers' self-efficacy beliefs as determinants of job satisfaction and students' academic achievement: A study at the school level. Journal of School Psychology, 44(6), 473-490. https://doi.org/10.1016/j.jsp.2006.09.001

Carson, R. L., Plemmons, S., Templin, T. J., \& Weiss, H. M. (2011). "You are who you are: “ A mixedmethod study of affectivity and emotion regulation in curbing teacher burnout. In G. M. Reevy \& E. Frydenberg (Eds.), Personality, stress, and coping: Implications for education (pp. 239-265). Information Age Publishing.

Chiu, M. M., \& Chow, B. W. Y. (2011). Classroom discipline across forty-one countries: School, economic, and cultural differences. Journal of Cross-Cultural Psychology, 42(3), 516-533. https://doi. org/10.1177/0022022110381115

Clotfelter, C. T., Ladd, H. F., \& Vigdor, J. L. (2007). Teacher credentials and student achievement: Longitudinal analysis with student fixed effects. Economics of Education Review, 26(6), 673-682. https://doi.org/10.1016/j.econedurev.2007.10.002

Cochran-Smith, M., Baker, M., Burton, S., Chang, W.-C., Cummings Carney, M., Fernández, M. B., Stringer Keefe, E., Miller, A. F., \& Sánchez, J. G. (2017). The accountability era in US teacher education: Looking back, looking forward. European Journal of Teacher Education, 40(5), 572-588. https://doi.org/10.1080/02619768.2017.1385061

Day, C. (2008). Committed for life? Variations in teachers' work, lives, and effectiveness. Journal of Educational Change, 9(3), 243-260. https://doi.org/10.1007/s10833-007-9054-6 
den Brok, P., Wubbels, T., \& van Tartwijk, J. (2017). Exploring beginning teachers' attrition in the Netherlands. Teachers and Teaching: Theory and Practice, 23(8), 881-895. https://doi.org/10. 1080/13540602.2017.1360859

Dou, D., Devos, G., \& Valcke, M. (2017). The relationships between school autonomy gap, principal leadership, teachers' job satisfaction and organizational commitment. Educational Management Administration \& Leadership, 45(6), 959-977. https://doi.org/10.1177/1741143216653975

Drossel, K., Eickelmann, B., van Ophuysen, S., \& Bos, W. (2019). Why teachers cooperate: An expectancy-value model of teacher cooperation. European Journal of Psychology of Education, 34(1), 187-208. https://doi.org/10.1007/s10212-018-0368-y

Ellison, S., Anderson, A. B., Aronson, B., \& Clausen, C. (2018). From objects to subjects: Repositioning teachers as policy actors doing policy work. Teaching and Teacher Education, 74, 157-169. https://doi.org/10.1016/j.tate.2018.05.001

Flores, M. A. (2014). Profissionalismo e liderança dos professores [Professionalism and teachers' leadership]. De Facto Editores.

Gersten, R. (2001). Sorting out the roles of research in the improvement of practice. Learning Disabilities Research \& Practice, 16(1), 45-50. https://doi.org/10.1111/0938-8982.00005

Ghavifekr, S., \& Pillai, N. S. (2016). The relationship between school's organizational climate and teacher's job satisfaction: Malaysian experience. Asia Pacific Education Review, 17(1), 87-106. https://doi.org/10.1007/s12564-015-9411-8

Giambona, F., \& Porcu, M. (2018). School size and students' achievement. Empirical evidences from PISA survey data. Socio-Economic Planning Sciences, 64, 66-77. https://doi.org/10.1016/j.seps.2017. 12.007

Gil-Flores, J. (2017). The role of personal characteristics and school characteristics in explaining teacher job satisfaction. Revista de Psicodidáctica, 22(1), 16-22. https://doi.org/10.1016/S11361034(17)30039-4

Glazer, J. (2018). Learning from those who no longer teach: Viewing teacher attrition through a resistance lens. Teaching and Teacher Education, 74, 62-71. https://doi.org/10.1016/j.tate.2018.04.011

Hahs-Vaughn, D. L., \& Scherff, L. (2008). Beginning English teacher attrition, mobility, and retention. The Journal of Experimental Education, 77(1), 21-54. https://doi.org/10.3200/JEXE.77.1.21-54

Han, S. W., Borgonovi, F., \& Guerriero, S. (2018). What motivates high school students to want to be teachers? The role of salary, working conditions, and societal evaluations about occupations in a comparative perspective. American Educational Research Journal, 55(1), 3-39. https://doi.org/10. 3102/0002831217729875

Heck, R. H., Thomas, S. L., \& Tabat, L. N. (2010). Multilevel and longitudinal modeling with IBM SPSS. Routledge.

Hecker, T., Goessmann, K., Nkuba, M., \& Hermenau, K. (2018). Teachers' stress intensifies violent disciplining in Tanzanian secondary schools. Child Abuse \& Neglect, 76, 173-183. https://doi.org/10. 1016/j.chiabu.2017.10.019

Henry, G. T., Bastian, K. C., \& Fortner, C. K. (2011). Stayers and leavers: Early-career teacher effectiveness and attrition. Educational Researcher, 40(6), 271-280. https://doi.org/10.3102/0013189X1141 9042

Ingersoll, R. M., \& Collins, G. J. (2017). Accountability and control in American schools*. Journal of Curriculum Studies, 49(1), 75-95. https://doi.org/10.1080/00220272.2016.1205142

Jesus, S. N. (1996). A motivação para a profissão docente: Contributo para a clarificação de situações de mal-estar e para a fundamentação de estratégias de formação de professores [Motivation for the teaching profession: Contribution to the clarification of uneasiness situations and to the foundation of teacher education strategies]. Estante Editora.

Jesus, S. N., \& Lens, W. (2005). An integrated model for the study of teacher motivation. Applied Psychology: An International Review, 54(1), 119-134. https://doi.org/10.1111/j.1464-0597.2005. 00199.x

Klassen, R. M., \& Chiu, M. M. (2010). Effects on teachers' self-efficacy and job satisfaction: Teacher gender, years of experience, and job stress. Journal of Educational Psychology, 102(3), 741-756. https://doi.org/10.1037/a0019237 
Kwantes, C. T. (2010). The facets of job satisfaction: A nine-nation comparative study of construct equivalence. Applied Multivariate Research, 13(2), 145-159. https://doi.org/10.22329/amr.v13i2. 3021

Lewis, R., Romi, S., Qui, X., \& Katz, Y. J. (2005). Teachers' classroom discipline and student misbehavior in Australia, China and Israel. Teaching and Teacher Education, 21(6), 729-741. https://doi.org/10. 1016/j.tate.2005.05.008

Li, M., \& Wang, Z. (2016). Emotional labour strategies as mediators of the relationship between public service motivation and job satisfaction in Chinese teachers. International Journal of Psychology, 51(3), 177-184. https://doi.org/10.1002/ijop.12114

Lincove, J. A., Osborne, C., Mills, N., \& Bellows, L. (2015). Teacher preparation for profit or prestige: Analysis of a diverse market for teacher preparation. Journal of Teacher Education, 66(5), 415-434. https://doi.org/10.1177/0022487115602311

Lopes, J., \& Oliveira, C. (2017). Classroom discipline: Theory and practice. In J. P. Bakken (Ed.), Classrooms: Academic content and behavior strategy instruction for students with and without disabilities (Vol. 2, pp. 231-253). Nova Science Publishers.

Malinen, O.-P., \& Savolainen, H. (2016). The effect of perceived school climate and teacher efficacy in behavior management on job satisfaction and burnout: A longitudinal study. Teaching and Teacher Education, 60, 144-152. https://doi.org/10.1016/j.tate.2016.08.012

Martin, N. K., Sass, D. A., \& Schmitt, T. A. (2012). Teacher efficacy in student engagement, instructional management, student stressors, and burnout: A theoretical model using in-class variables to predict teachers' intent-to-leave. Teaching and Teacher Education, 28(4), 546-559. https://doi. org/10.1016/j.tate.2011.12.003

McInerney, D. M., Korpershoek, H., Wang, H., \& Morin, A. J. S. (2018). Teachers' occupational attributes and their psychological wellbeing, job satisfaction, occupational self-concept and quitting intentions. Teaching and Teacher Education, 71, 145-158. https://doi.org/10.1016/j.tate.2017.12.020

Menon, M. E., \& Athanasoula-Reppa, A. (2011). Job satisfaction among secondary school teachers: The role of gender and experience. School Leadership \& Management, 31(5), 435-450. https:// doi.org/10.1080/13632434.2011.614942

Muthén, B. O., \& Satorra, A. (1995). Complex sample data in structural equation modeling. Sociological Methodology, 25, 267-316. https://doi.org/10.2307/271070

Nakata, A., Irie, M., \& Takahashi, M. (2013). A single-item global job satisfaction measure is associated with quantitative blood immune indices in white-collar employees. Industrial Health, 51(2), 193-201. https://doi.org/10.2486/indhealth.2012-0059

Organisation for Economic Co-operation and Development. (2014a). TALIS 2013 results: An international perspective on teaching and learning. https://doi.org/10.1787/9789264196261-en

Organisation for Economic Co-operation and Development. (2014b). TALIS 2013 technical report.

Pedder, D. (2006). Are small classes better? Understanding relationships between class size, classroom processes and pupils' learning. Oxford Review of Education, 32(2), 213-234. https://doi. org/10.1080/03054980600645396

Pepe, A., Addimando, L., \& Veronese, G. (2017). Measuring teacher job satisfaction: Assessing invariance in the teacher job satisfaction scale (TJSS) across six countries. Europe's Journal of Psychology, 13(3), 396-416. https://doi.org/10.5964/ejop.v13i3.1389

Peugh, J. L. (2010). A practical guide to multilevel modeling. Journal of School Psychology, 48(1), 85-112. https://doi.org/10.1016/j.jsp.2009.09.002

Raudenbush, S. W., Bryk, A. S., \& Congdon, R. (2013). HLM 7.01 for Windows [Computer software]. Scientific Software International.

Roberts, M. R., \& Whited, T. M. (2013). Endogeneity in empirical corporate finance. In G. M. Constantinides, M. Harris, \& R. M. Stulz (Eds.), Handbook of the economics of finance: Vol. $2 A$. Corporate finance (pp. 493-572). North-Holland.

Ronfeldt, M., Loeb, S., \& Wyckoff, J. (2013). How teacher turnover harms student achievement. American Educational Research Journal, 50(1), 4-36. https://doi.org/10.3102/0002831212463813

Ryan, S. V., von der Embse, N. P., Pendergast, L. L., Saeki, E., Segool, N., \& Schwing, S. (2017). Leaving the teaching profession: The role of teacher stress and educational accountability policies on turnover intent. Teaching and Teacher Education, 66, 1-11. https://doi.org/10.1016/j.tate.2017.03.016 
Saeki, E., Segool, N., Pendergast, L., \& von der Embse, N. (2018). The influence of test-based accountability policies on early elementary teachers: School climate, environmental stress, and teacher stress. Psychology in the Schools, 55(4), 391-403. https://doi.org/10.1002/pits.22112

Sezgin, F. (2010). School culture as a predictor of teachers' organizational commitment. Egitim ve Bilim, 35(156), 142-159.

Shen, J., Leslie, J. M., Spybrook, J. K., \& Ma, X. (2012). Are principal background and school processes related to teacher job satisfaction? A multilevel study using schools and staffing survey 2003-04. American Educational Research Journal, 49(2), 200-230. https://doi.org/10.3102/000283121141 9949

Shoshani, A., \& Eldor, L. (2016). The informal learning of teachers: Learning climate, job satisfaction and teachers' and students' motivation and well-being. International Journal of Educational Research, 79, 52-63. https://doi.org/10.1016/j.ijer.2016.06.007

Simón, C., \& Alonso-Tapia, J. (2016). Positive classroom management: Effects of disruption management climate on behaviour and satisfaction with teacher. Revista de Psicodidáctica, 21(1), 65-86. https://doi.org/10.1387/RevPsicodidact.13202

Sims, S. (2017). TALIS 2013: Working conditions, teacher job satisfaction and retention [Statistical working paper]. Department for Education.

Skaalvik, E. M., \& Skaalvik, S. (2011). Teacher job satisfaction and motivation to leave the teaching profession: Relations with school context, feeling of belonging, and emotional exhaustion. Teaching and Teacher Education, 27(6), 1029-1038. https://doi.org/10.1016/j.tate.2011.04.001

Skaalvik, E. M., \& Skaalvik, S. (2014). Teacher self-efficacy and perceived autonomy: Relations with teacher engagement, job satisfaction, and emotional exhaustion. Psychological Reports, 114(1), 68-77. https://doi.org/10.2466/14.02.PR0.114k14w0

Skaalvik, E. M., \& Skaalvik, S. (2015). Job satisfaction, stress and coping strategies in the teaching profession - What do teachers say? International Education Studies, 8(3), 181-192. https://doi.org/10. 5539/ies.v8n3p181

Sugrue, C., \& Mertkan, S. (2017). Professional responsibility, accountability and performativity among teachers: The leavening influence of CPD? Teachers and Teaching: Theory and Practice, 23(2), 171-190. https://doi.org/10.1080/13540602.2016.1203771

Sun, A., \& Xia, J. (2018). Teacher-perceived distributed leadership, teacher self-efficacy and job satisfaction: A multilevel SEM approach using the 2013 TALIS data. International Journal of Educational Research, 92, 86-97. https://doi.org/10.1016/j.ijer.2018.09.006

Organisation for Economic Co-operation and Development. (2010). TALIS 2008: Technical report. https://doi.org/10.1787/9789264079861-en

Torres, D. G. (2018). Distributed leadership and teacher job satisfaction in Singapore. Journal of Educational Administration, 56(1), 127-142. https://doi.org/10.1108/JEA-12-2016-0140

Tsouloupas, C. N., Carson, R. L., \& Matthews, R. A. (2014). Personal and school cultural factors associated with the perceptions of teachers' efficacy in handling student misbehavior. Psychology in the Schools, 51(2), 164-180. https://doi.org/10.1002/pits.21739

Tuytens, M., \& Devos, G. (2018). Teacher evaluation policy as perceived by school principals: The case of Flanders (Belgium). Teachers and Teaching: Theory and Practice, 24(3), 209-222. https://doi.org/ 10.1080/13540602.2017.1397508

UNESCO Institute for Statistics. (2017). Teacher attrition rate by teaching level of education. http://data.uis.unesco.org/index.aspx?queryid $=203$

von der Embse, N. P., Sandilos, L. E., Pendergast, L., \& Mankin, A. (2016). Teacher stress, teachingefficacy, and job satisfaction in response to test-based educational accountability policies. Learning and Individual Differences, 50, 308-317. https://doi.org/10.1016/j.lindif.2016.08.001

von der Embse, N. P., Schoemann, A. M., Kilgus, S. P., Wicoff, M., \& Bowler, M. (2017). The influence of test-based accountability policies on teacher stress and instructional practices: A moderated mediation model. Educational Psychology, 37(3), 312-331. https://doi.org/10.1080/01443410. 2016.1183766

Wang, H., Hall, N. C., \& Rahimi, S. (2015). Self-efficacy and causal attributions in teachers: Effects on burnout, job satisfaction, illness, and quitting intentions. Teaching and Teacher Education, 47, 120-130. https://doi.org/10.1016/j.tate.2014.12.005 
Wang, K., Li, Y., Luo, W., \& Zhang, S. (2019). Selected factors contributing to teacher job satisfaction: A quantitative investigation using 2013 TALIS data. Leadership and Policy in Schools. Advance online publication. https://doi.org/10.1080/15700763.2019.1586963

Watson, K., Handal, B., \& Maher, M. (2017). Class size: Teachers' perspectives. Curriculum and Teaching, 32(2), 5-26. https://doi.org/10.7459/ct/32.2.02

Worrell, T. G., Skaggs, G. E., \& Brown, M. B. (2006). School psychologists' job satisfaction: A 22-year perspective in the USA. School Psychology International, 27(2), 131-145. https://doi.org/10.1177/ 0143034306064540

Wu, J.-Y., Hughes, J. N., \& Kwok, O.-M. (2010). Teacher-student relationship quality type in elementary grades: Effects on trajectories for achievement and engagement. Journal of School Psychology, 48(5), 357-387. https://doi.org/10.1016/j.jsp.2010.06.004

Zieger, L., Sims, S. \& Jerrim, J. (2019). Comparing teachers' job satisfaction across countries. A multiple-pairwise measurement invariance approach. Educational Measurement: Issues and Practice. Advance online publication. https://doi.org/10.1111/emip.12254 